\title{
Scale-dependent effects of land use on plant species richness of mountain grassland in the European Alps
}

\author{
Thomas Spiegelberger, Diethart Matthies, Heinz Müller-Schärer and Urs Schaffner
}

\begin{abstract}
Spiegelberger, T., Matthies, D., Müller-Schärer, H. and Schaffner, U. 2006. Scaledependent effects of land use on plant species richness of mountain grassland in the European Alps. - Ecography 29: 541-548.
\end{abstract}

Traditionally managed mountain grasslands in the Alps are species-rich ecosystems that developed during centuries of livestock grazing. However, changes in land use including fertilisation of well accessible pastures and gradual abandonment of remote sites are increasingly threatening this diversity. In five regions of the Swiss and French Alps we assessed the relationship between land use, soil resource availability, cover of the unpalatable species Veratrum album, species richness and vegetation composition of mountain grasslands across four spatial scales ranging from 1 to $1000 \mathrm{~m}^{2}$.

Mean species richness and the increase in the number of species with increasing area were lower in intensively grazed, fertilised pastures than in traditional pastures or in abandoned pastures. Species composition of abandoned pastures differed from that of the other management types. Plant species richness was influenced by different factors at different spatial scales. At the $1 \mathrm{~m}^{2}$ scale, plant species richness was negatively related to soil nitrate and influenced by the cover of $V$. album, depending on land use: species richness and cover of $V$. album were negatively correlated in abandoned pastures, but positively correlated in fertilised grasslands. At the $1000 \mathrm{~m}^{2}$ scale, a negative effect of fertilization on richness was evident. These results indicate that at small scales species richness in mountain grasslands is determined by competition for light, which should be more important if nutrient availability is high, and by positive and negative interactions with unpalatable plants. In contrast, species richness at the large scale appears to be mainly influenced by land use. This result emphasizes the importance of studying such inter-relationships at multiple scales. Our study further suggests that the maintenance of the traditional land use scheme is crucial for the conservation of plant species richness of mountain pastures as both intensification and abandonment changed species composition and reduced plant species diversity.

T. Spiegelberger, (t.spiegelberger@,cabi.org), CABI Bioscience Switzerland, Rue des Grillons 1, CH-2800 Delémont, Switzerland and Univ. of Fribourg, Dept of Biology, Unit Ecology and Evolution, Chemin du Musée 10, CH-1700 Fribourg, Switzerland. - D. Matthies, Univ. of Marburg, Dept of Biology, DE-35032 Marburg, Germany. - H. Müller-Schärer, Univ. of Fribourg, Dept of Biology, Unit Ecology and Evolution, Chemin du Musée 10, CH-1700 Fribourg, Switzerland. - U. Schaffner, CABI Bioscience Switzerland, Rue des Grillons 1, CH-2800 Delémont, Switzerland.

In recent years changes in land use and other human activities have resulted in a decrease in species richness world-wide (Hooper et al. 2005 and references therein). Species richness is seen as an insurance against a decline in ecosystem services, such as the prevention of soil erosion and maintenance of hydrological cycles, or in ecosystem goods, such as tourism and recreation (Hooper et al. 2005). In Europe, the diversity of grasslands has dramatically decreased in lowland areas, whereas many traditionally managed mountain

\footnotetext{
Accepted 24 April 2006 
grasslands are still species-rich (MacDonald et al. 2000). However, changes in land use are threatening these habitats as well. At present we see increasing intensification of the use of well accessible sites paralleled by abandonment of less accessible sites in the European Alps (Tasser and Tappeiner 2002). When traditionally managed mountain grasslands below the tree line are abandoned, their floristic composition changes and their agricultural quality decreases, leading in the long term to reforestation and a significant reduction in biodiversity (Fischer and Wipf 2002). This development is difficult to reverse (Stampfli and Zeiter 1999), because of limited seed dispersal, recruitment and micro-site availability (Tilman 1997, Zobel et al. 2000). Intensification, in particular the application of fertiliser, has also been shown to decrease the species richness of mountain grasslands (Theodose and Bowman 1997, Nagy et al. 2003).

Most studies of the effects of land use change on plant species richness and vegetation composition in mountain grasslands were carried out at very small scales (Stampfli and Zeiter 1999, Fischer and Wipf 2002, Tasser and Tappeiner 2002, Dullinger et al. 2003, Müller et al. 2003, Kleijn and Müller-Schärer in press). However, patterns in plant species richness and the underlying mechanisms can vary considerably among different spatial scales (Huston 1999 and references therein). At the scale of an individual pasture, the traditionally managed mountain grasslands are characterized by a large number of different microsites (Austrheim and Eriksson 2001, Erschbamer et al. 2003). This diversity of microsites can be explained by small-scale variation in topography and by the effects of grazing that increases the number of microhabitats through spatially heterogeneous defoliation, trampling, wallowing and faecal deposition (WallisDeVries et al. 1998). Heterogeneous sites consisting of a large number of different microsites are considered to support a large variety of plant species (Olff and Ritchie 1998). Both the fertilisation of grasslands, because it homogenises soil nutrients, and their abandonment, because the sites are no longer grazed, are likely to reduce the spatial heterogeneity. Hence, we hypothesize that species richness will decline in both cases. This process, however, may be scale-dependent since the degree of heterogeneity changes with spatial scales.

Unpalatable weeds are among the factors possibly influencing plant diversity and are strongly related to land use and land-use change in mountain grassland. One of the most prominent representatives of unpalatable weeds in the European Alps is Veratrum album (Liliaceae), a large, highly toxic monocot native to Europe and Asia. It has attained pest status in France, Switzerland, Italy, Austria and Slovenia (FAO unpubl.). Because of its tall growth, it may negatively affect species richness at small scales simply due to competition for space (Crawley and Harral 2001). However, when grazing is intense, unpalatable plants may act as facilitator species that enhance plant species richness (Bertness and Callaway 1994, Callaway et al. 2005). This suggests that the effect of unpalatable plants on species richness may depend on management. Furthermore, the interrelationship between species richness and weed abundance may also vary across spatial scales within a single management type. For example, while competition may lead to a negative relationship between weed abundance and species richness at small scales, extrinsic factors such as disturbance or propagule supply may affect species richness and weed abundance in a similar way at larger scales and thereby mask factors operating at neighbourhood scales (Levine et al. 2002). In a study in mountain grasslands of the Rocky Mountains, Stohlgren et al. (1999) found that native species richness and number of exotic weeds were negatively correlated at small scales $\left(1 \mathrm{~m}^{2}\right)$, but positively correlated at large scales $\left(1000 \mathrm{~m}^{2}\right)$.

The aim of this study was to investigate the effects of land use, soil properties, and the abundance of $V$. album on the species richness of mountain grasslands at four spatial scales. We addressed the following questions: 1) is there an effect of land use on plant species richness and is this effect scale-dependent? 2) How well do management, soil chemistry and the abundance of $V$. album explain plant species richness at small and at large spatial scales? 3) Does the effect of $V$. album on plant species richness depend on land use and spatial scale?

\section{Methods}

\section{Study sites}

Fifteen sites below the tree line with a high presence of the unpalatable plant Veratrum album (Liliaceae) were selected in five different regions of the Alps (Beaufortin, Bauges, Chablais in France, and Chablais and Lac de Dix in Switzerland, cf. Appendix 1). Veratrum album is an important weed of many mountain grasslands. It is typically found in natural grasslands above the tree line and in open woodlands, but has invaded semi-natural grasslands below the tree line. Large herbivores do not browse on $V$. album due to the high alkaloid concentration in all plant parts (Binns et al. 1972; for more details see Kleijn and Steinger 2002).

Within each region three sites were selected: a traditionally used unfertilised pasture (hereafter called "traditional pasture"), a grazed and fertilised pasture ("fertilised pasture"), and a grassland that had been abandoned for at least $5 \mathrm{yr}$ ("abandoned pasture"). In the following we refer to these three categories as "land use" and to grazing or fertilisation as "management". Fertilised grasslands had received either inorganic fertiliser or liquid manure for several years. Because abandoned pastures were rarest, they were chosen first. Then, 
the other two pasture types were selected within $5 \mathrm{~km}$ of this site, as similar as possible with regard to altitude, exposition and inclination. Information about time since abandonment, fertiliser application and duration of application were obtained from the farmers.

\section{Vegetation and soil}

At each site one modified Whittaker plot (MWP, Stohlgren et al. 1999) of $50 \times 20 \mathrm{~m}$ was established in an homogeneously managed area (cf. Fig. 1). The minimum distance to adjacent areas with different land use was at least $15 \mathrm{~m}$ for abandoned sites and $50 \mathrm{~m}$ for sites with other management. The MWP was placed with its long side along the main slope. Nested in the MWP was one $100 \mathrm{~m}^{2}$ subplot $(5 \times 20 \mathrm{~m})$ in the centre and two $10 \mathrm{~m}^{2}$ subplots $(5 \times 2 \mathrm{~m})$ in opposite corners of the plot. Ten $1 \mathrm{~m}^{2}$ subplots (each $0.5 \times 2 \mathrm{~m}$ ) were regularly spaced within the MWP, six of them along the inner border of the $1000 \mathrm{~m}^{2}$ plot and four along the outer border of the central $100 \mathrm{~m}^{2}$ subplot. For each MWP, elevation and main exposition in degrees from north were recorded with a GPS and the inclination of the slope was calculated using the elevation of the upper and lower corner of the MWP recorded by the GPS. All sites were sampled in summer 2003 or 2004.

In the $1 \mathrm{~m}^{2}$ subplots of the MWP, the foliar cover of all plant species and the area covered by bare ground and rocks were estimated to the nearest percent. Species with a cover of $<1 \%$ were assigned a cover value of $0.5 \%$. Species richness (total number of species in a sample area) was recorded separately at each scale and each plot.

Twelve soil samples were taken in each $1 \mathrm{~m}^{2}$ plot (ø 2.5 $\mathrm{cm}$, depth $10 \mathrm{~cm}$ ) to analyse soil chemical properties and moisture content. Soil samples were pooled per $1 \mathrm{~m}^{2}$ plot, transferred to a deep-freezer $\left(-18^{\circ} \mathrm{C}\right)$ within a few hours after sampling and kept frozen until further processing. $\mathrm{NH}_{4}$ and $\mathrm{NO}_{3}$-concentrations were measured with a colorimeter (Flow analyser, Skalar San

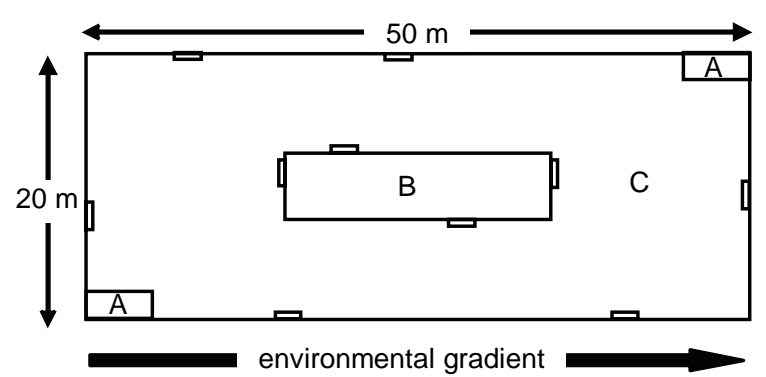

Fig. 1. Layout of the modified Whittaker plot (MWP) to study plant species diversity. The $1000 \mathrm{~m}^{2}$ whole plot (C) contains one $100 \mathrm{~m}^{2}$ subplot $(\mathrm{B}, 5 \times 20 \mathrm{~m})$, two $10 \mathrm{~m}^{2}$ subplots $(\mathrm{A}, 5 \times 2 \mathrm{~m})$ and ten $1 \mathrm{~m}^{2}$ subplots $(0.5 \times 2 \mathrm{~m})$.
Plus, The Netherlands) after solving $50 \mathrm{~g}$ soil in $250 \mathrm{ml}$ of $1 \mathrm{~m} \mathrm{KCl}$, and ortho-phosphate with the Olsen method (Olsen et al. 1954). Soil pH was measured after shaking 1 $\mathrm{ml}$ soil in $5 \mathrm{ml}$ distilled water (all analyses were carried out by SADEF, Aspach, France).

\section{Statistical analysis}

Cover data were used to calculate the mean Ellenberg light indicator value (mL, Ellenberg et al. 1991) for each $1 \mathrm{~m}^{2}$ plot as $\mathrm{mL}=\Sigma \mathrm{L}_{\mathrm{i}} \times \mathrm{p}_{\mathrm{i}}$, where $\mathrm{L}_{\mathrm{i}}$ is the light indicator value of species $\mathrm{i}$ and pi its relative abundance. Mean Ellenberg nitrogen $(\mathrm{mN})$, humidity $(\mathrm{mH})$ and reaction indicator values $(\mathrm{mR})$ were computed analogously. To elucidate differences among land use types with regard to site and soil characteristics, vegetation diversity indices, mean Ellenberg indicator values, and $V$. album and grass cover, ANOVAs were carried out using region $(n=5)$ and land use type $(n=3)$ as fixed factors. If an ANOVA revealed significant effects, Tukey's HSD test was used to identify significant differences between types of land use at the $\mathrm{p}<0.05$ level. The effect of management type (grazing, fertilisation) on species richness across multiple scales $\left(1-1000 \mathrm{~m}^{2}\right)$ was assessed using a hierarchical general linear model with region, grazing, fertilisation and $\log ($ area) as fixed factors and site as a random factor. In this model, the sums of squares for each factor were adjusted for all factors that preceded it in the model.

To examine whether plant species richness was affected by different factors at different spatial scales, we calculated two separate hierarchical general linear models using the data from the smallest and the largest sampling scale $\left(1\right.$ and $1000 \mathrm{~m}^{2}$ ). At the $1 \mathrm{~m}^{2}$ scale, the model included region, grazing and fertilisation as fixed factors, site as a random factor, and nitrate, ammonium, total phosphate, $\mathrm{pH}$, and cover of $V$. album as covariates. Soil variables were not or only moderately correlated with each other (all $\mathrm{r}<0.4)$. We subsequently removed non-significant variables, but because we were specifically interested in the effect of $V$. album on plant species richness, we kept the cover of $V$. album and its interactions with grazing and fertilisation in the reduced models. Because the full model that included all soil variables at the $1 \mathrm{~m}^{2}$ scale was not significantly different from the reduced model with nitrate as only soil variable (ANOVA, $\mathrm{p}>0.6$ ), the simpler model was preferred. Similarly, at the $1000 \mathrm{~m}^{2}$ scale, the model contained region, grazing and fertilisation as fixed factors, and nitrate and cover of $V$. album as covariates.

To assess whether vegetation composition differed among land use types, the log-transformed cover values of the species in the $1 \mathrm{~m}^{2}$ plots were analysed by the ordination technique non-metric multidimensional scaling (NMDS, Shepard 1962, Kruskal 1964), with the 
Bray-Curtis coefficient as distance measure. NMDS is commonly seen as the most robust unconstrained ordination method in community ecology (Minchin 1987). To find indicator species for the different land use types, indicator species analyses (Dufrene and Legendre 1997) followed by a randomisation test were carried out with the log-transformed cover data.

All statistical analyses were carried out using the $\mathrm{R}$ statistical language (<http://cran.r-project.org/ $>$ ), except for the indicator species analyses which were carried out with PC-ORD (McCune and Mefford 1999).

\section{Results}

\section{Site characteristics}

Elevation, inclination of the slope, exposition of the MWPs, and all soil variables measured did not differ among the land use types (ANOVA, all $\mathrm{p}>0.15$ ), but elevation $\left(\mathrm{F}_{4,8}=7.4\right)$ and exposition $\left(\mathrm{F}_{4,8}=7.1\right.$, both $\mathrm{p}<$ $0.01)$ differed significantly among regions.

\section{Plant species richness}

Plant species richness was significantly lower in fertilised pastures than in traditional pastures pooled over all scales (Table 1, Fig. 2). The slope of the species-area relationship was lower in the fertilised than in the traditionally used, unfertilised pastures (see significant interaction between the effects of fertilisation and spatial scale in Table 1, Fig. 2). As a consequence, species richness at $1000 \mathrm{~m}^{2}$ was much higher in traditionally used grasslands $(73.6 \pm 2.01$ species $)$ than in fertilised grasslands $(54.8 \pm 1.48)$, while species richness at abandoned sites $(62.8 \pm 2.10)$ was intermediate (ANOVA, $\mathrm{F}_{2,8}=4.26, \mathrm{p}=0.055$; followed by Tukey's HSD test).

Plant species richness was influenced by different variables at different spatial scales (Table 2). At the 1

Table 1. General linear model of the effects of region, grazing, fertilisation and survey area on the number of plant species in mountain pastures of the Alps. The effects of region, grazing and fertiliser were tested against the residual variation among sites, all other effects against the residual. Significant $\mathrm{p}$-values $(\mathrm{p}<0.05)$ are in bold-face.

\begin{tabular}{lrrr}
\hline Source & DF & \multicolumn{1}{c}{$\mathrm{F}$} & \multicolumn{1}{c}{$\mathrm{p}$} \\
\hline Region & 4 & 1.23 & 0.371 \\
Grazing & 1 & 0.32 & 0.586 \\
Fertiliser (within grazing) & 1 & 5.63 & $\mathbf{0 . 0 4 5}$ \\
Site & 8 & 11.04 & $<\mathbf{0 . 0 0 1}$ \\
Log (area) & 1 & 578.58 & $<\mathbf{0 . 0 0 1}$ \\
Region $\times$ Log (area) & 4 & 7.80 & $<\mathbf{0 . 0 0 1}$ \\
Grazing $\times$ Log (area) & 1 & 0.07 & 0.796 \\
Fertiliser $\times$ Log (area) & 1 & 11.02 & $\mathbf{0 . 0 0 2}$ \\
Residual & 38 & & \\
Total & 60 & & \\
\hline
\end{tabular}

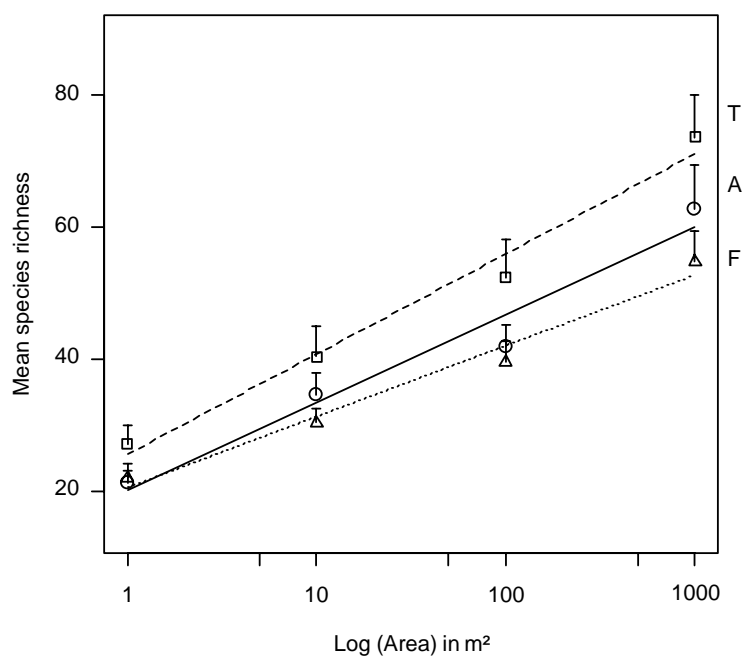

Fig. 2. Species-area relationship in mountain pastures of the Alps that had been subjected to different types of land use. Error bars indicate one standard error for each combination of land use type and area. Triangles: fertilised pastures $(\mathrm{F})$; squares: traditional pastures (T); circles: abandoned pastures (A).

$\mathrm{m}^{2}$ level, species richness was negatively related to nitrate and cover of $V$. album. Nitrate concentration and cover of $V$. album were not correlated with each other $(\mathrm{p}>$ 0.4 ). At the $1000 \mathrm{~m}^{2}$ level, species richness was negatively affected by fertilisation, and only marginally negatively correlated with nitrate.

\section{Vegetation composition}

Plant species composition did not differ between regions (ANOVA of NMDS scores along axis $1, \mathrm{p}>0.05$ ), but was influenced by land use $\left(\mathrm{F}_{2,8}=4.61, \mathrm{p}=0.047\right)$, probably due to change in grass cover. The cover of grasses was highest in fertilised pastures $(49.9 \pm 1.3)$, lower in traditional pastures $(40.8 \pm 1.4)$ and lowest in abandoned pastures $(30.3 \pm 2.8)$ (ANOVA, $F_{2,8}=4.91$, $\mathrm{p}=0.040$, followed by Tukey's HSD). Abandoned sites had significantly lower scores along the first NMDS axis than the two other types of land use (Tukey's HSD; Fig. 3 ). The scores along the first NMDS axis were negatively correlated with the Ellenberg indicator value for soil reaction $(\mathrm{r}=0.91)$ and soil nitrogen $(\mathrm{r}=0.81)$, suggesting that plants that typically grow at higher $\mathrm{pH}$ values and higher nutrient availability were more abundant in abandoned pastures. The mean light indicator value was positively related to the first NMDS axis $(r=0.74)$, suggesting that abandoned pastures contain more shadetolerant plants than sites subjected to the two other types of land use (for all linear regressions: $\mathrm{DF}=13$, $\mathrm{p}<0.001)$.

Mean Ellenberg indicator values for soil reaction $\left(\mathrm{F}_{2,8}=4.39, \mathrm{p}=0.051\right)$ and light $\left(\mathrm{F}_{2,8}=3.34, \mathrm{p}=0.088\right)$ were marginally different between land use types. 
Table 2. General linear model of the effects of region, grazing, fertiliser, cover of $V$. album, and soil nitrate concentration on plant species richness in mountain pastures of the Alps at two spatial scales. The effects of region, grazing and fertiliser were tested against the residual variation among sites, all other effects against the residual. Marginally significant $p$-values $(0.1>p>0.05)$ are in italics, significant $p$-values $(p<0.05)$ are in bold-face.

\begin{tabular}{|c|c|c|c|c|c|c|}
\hline \multirow[b]{2}{*}{ Source } & \multicolumn{3}{|c|}{ Species richness at $1 \mathrm{~m}^{2}$} & \multicolumn{3}{|c|}{ Species richness at $1000 \mathrm{~m}^{2}$} \\
\hline & DF & $\mathrm{F}$ & $\mathrm{p}$ & DF & $\mathrm{F}$ & $\mathrm{p}$ \\
\hline Region & 4 & 0.29 & 0.878 & 4 & 7.06 & 0.042 \\
\hline Grazing & 1 & 1.08 & 0.330 & 1 & 0.14 & 0.725 \\
\hline Fertiliser & 1 & 1.76 & 0.222 & 1 & 19.30 & 0.012 \\
\hline Site & 8 & 23.09 & $<\mathbf{0 . 0 0 1}$ & - & - & - \\
\hline Nitrate & 1 & 9.81 & 0.002 & 1 & 4.65 & 0.097 \\
\hline Cover of $V$. album & 1 & 4.51 & 0.035 & 1 & 1.20 & 0.336 \\
\hline$V$. album $\times$ grazing & 1 & 0.01 & 0.923 & 1 & 3.36 & 0.141 \\
\hline V. album $\times$ fertiliser & 1 & 2.89 & 0.092 & 1 & 5.06 & 0.088 \\
\hline Residual & 130 & & & 4 & & \\
\hline Total & 149 & & & 15 & & \\
\hline
\end{tabular}

Abandoned pastures had the lowest indicator values for light $(6.7 \pm 0.05)$ and the highest for soil reaction $(6.4 \pm$ 0.05 ) and those were significantly different from those for the other two types of land use (fertilised pastures: $\mathrm{mL} 7.3 \pm 0.03$, $\mathrm{mR} 5.5 \pm 0.15$; traditional pastures: $\mathrm{mL}$ $7.1 \pm 0.06 ; \mathrm{mR} 5.6 \pm 0.11$ ).

\section{Veratrum album and land use}

The cover of $V$. album did not differ among land use types at any spatial scale (all $p>0.75$ ), but the marginally significant interaction between the effects of fertilisation and cover of $V$. album at both scales on species richness (Table 2) suggested management-dependent effects of $V$. album on species richness. Linear regressions of species richness at the $1 \mathrm{~m}^{2}$ scale on the abundance of $V$. album revealed different effects, depending on land use (Fig. 4). In abandoned pastures, species richness was negatively related to the cover of $V$. album, whereas the opposite was true for fertilised

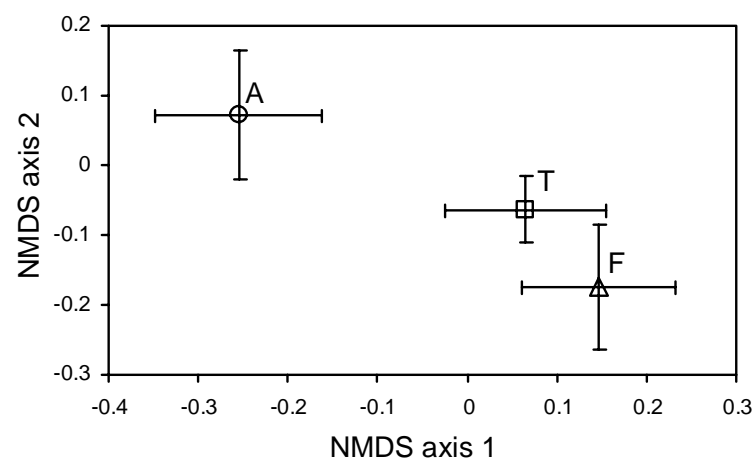

Fig. 3. Ordination diagram of a non-metric multi-dimensional scaling of the vegetational composition of mountain pastures in the Alps with different land use. Fertilised pastures (F); traditional pastures (T); abandoned pastures (A). The first NMDS axis was negatively correlated with the mean Ellenberg indicator value for soil reaction and soil nitrogen, and positively with the mean light indicator value. grasslands; in traditional pastures species richness was not related to the abundance of $V$. album. At the large scale $\left(1000 \mathrm{~m}^{2}\right)$ there was no relationship between species richness and V. album $(\mathrm{p}>0.3)$, but statistical power was low ( $\mathrm{n}=5$ for each land use type).

\section{Discussion}

\section{Land use, spatial scale and vegetation}

Our results suggest that the effect of land use on plant species richness in mountain grasslands is scale-dependent. Fertilised pastures had an overall lower species richness, and the increase in species richness with area was smaller in fertilised pastures than in traditional pastures (cf. Fig. 2, Table 1). The different increase in species richness with area may be explained by the varying degree of heterogeneity at a given spatial scale. At the smallest scale, the ecological interactions between individual plants appear to differ among land use types, as indicated by the different vegetation composition, but they result in a similar plant species richness. At the scale of pastures, factors such as geology, topography, hydrology and management are considered to be main determinants of plant species richness by creating a matrix of habitats with variable plant species composition (Crawley and Harral 2001). This is in agreement with our findings, indicating that at the scale of $1000 \mathrm{~m}^{2}$ traditional pastures harbour a more diverse matrix of habitats than fertilized pastures. We hypothesize that fertiliser application has lead to the homogenisation of some of the heterogeneity initially present at the largest scale. As a consequence, fertilised plant communities were dominated by a few plant species (mainly grasses) well adapted to the increased availability of nutrients and to intense grazing pressure, whereas the traditional pastures contained a high number of subdominant species with different micro-habitat requirements (Appendix 2). 

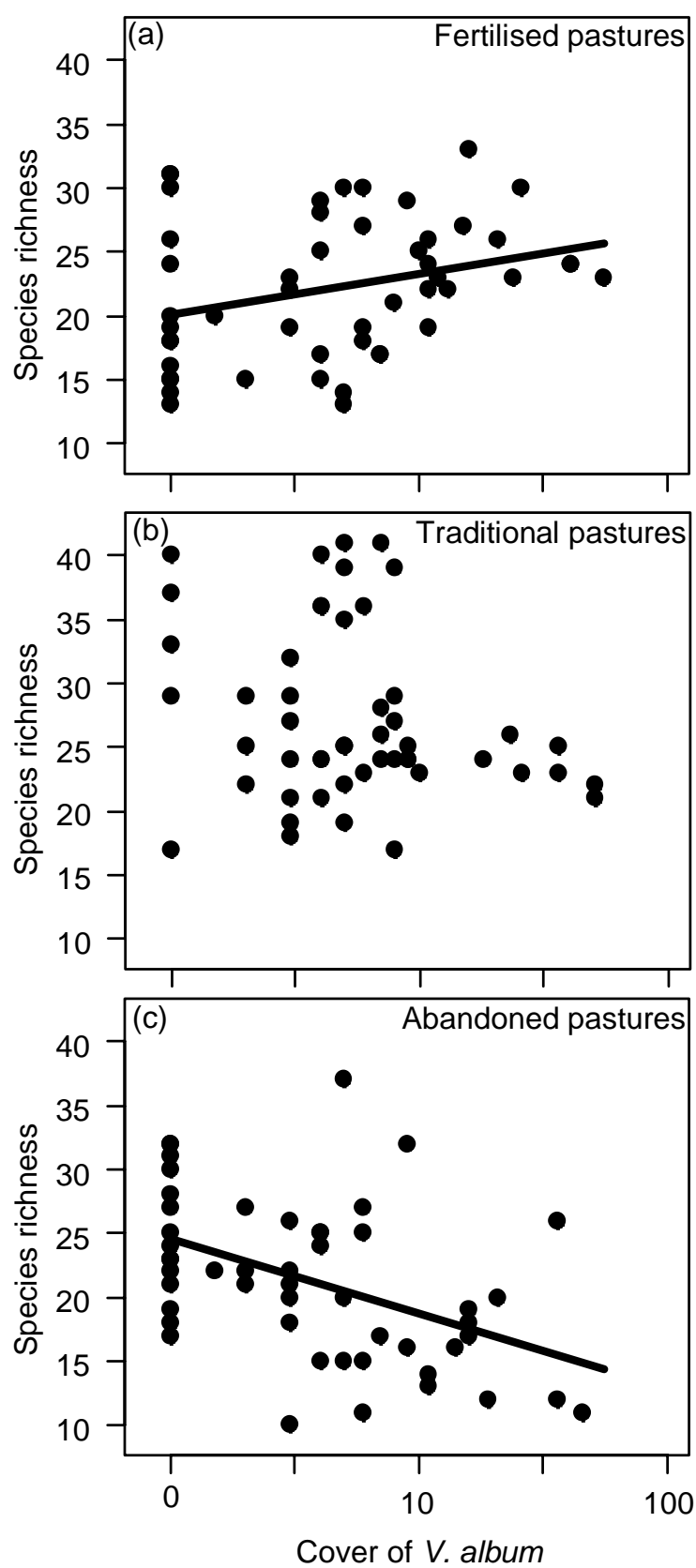

Fig. 4. The relationship between the species richness in $1 \mathrm{~m}^{2}$ plots and the cover of the unpalatable plant Veratrum album at sites with different management in the Alps, (a) Fertilised $(r=$ $0.30, \mathrm{p}<0.05)$, (b) traditionally used $(\mathrm{p}>0.1)$, and (c) abandoned $(\mathrm{r}=-0.46, \mathrm{p}<0.001)$ mountain pastures $(\mathrm{n}=50$ for each type of land use).

Apart from spatial heterogeneity, species richness of grasslands may also be strongly influenced by the disturbance regime (Milchunas et al. 1988). In agreement with the intermediate disturbance hypothesis (Connell 1978, Huston 1979), we found the species richest communities in traditional pastures, where the level of disturbance is intermediate between that at fertilized and abandoned sites. Grazing pressure and thus disturbance is high in fertilised pastures, whereas at abandoned sites there is no grazing and thus little disturbance. In fertilized pastures mainly grasses were found as characteristic species (Appendix 2). In mountain grasslands, most forbs are adapted to low nutrient conditions and less tolerant to grazing than grasses (Oksanen 1990, Oksanen and Moen 1994). At fertilised sites with intense grazing pressure grasses may thus outcompete the less grazing-tolerant forbs. In the case of abandoned sites, shade-tolerant species (e.g. Chaerophyllum hirsutum, Geranium sylvaticum, Equisetum sylvaticum; Appendix 2) were more dominant, suggesting increased competition for light.

The plant community of abandoned grasslands differed from that of traditional and fertilised pastures, although the sites had only been abandoned for 5-40 yr. In mountain grasslands of the Alps shifts in vegetational composition can occur rapidly and may be already detectable four years after abandonment (Stampfli 1992). The absence of continuous grazing by livestock allowed some common forest species to establish and spread, but at the same time reduced the abundance of a number of uncommon or rare plant species characteristic for traditional pastures, such as Arnica montana and Orchis maculata (Appendix 2). Thus, abandonment resulted in a decrease in conservation value due to changes in species composition even though species richness did not decline significantly.

\section{Scale-dependent responses of species richness}

Our study indicates that factors influencing species richness in mountain grasslands vary with scale, probably due to different mechanisms operating at different scales. For example, at small spatial scales interactions between $V$. album and other plant species as well as soil nitrate concentration influenced species richness. At small spatial scales in grasslands, competition for space generally is very important (Tilman 1994). Veratrum album is one of the tallest and largest plants of its community. It is also one of the first plants that starts growing in spring and it reaches its maximal shoot biomass about two months before most other plants (Kleijn and Müller-Schärer in press). It therefore may have a competitive advantage over smaller forbs and grasses due to asymmetric competition for light (Newman 1973).

Ammonium was the predominant form of inorganic soil nitrogen in our study sites, which is typical for many mountain areas (Körner 1999). Nevertheless, species richness was not influenced by ammonium, but by nitrate levels. Nutrient enrichment experiments at arctic and alpine sites revealed that a higher availability of 
nitrogen increases the productivity of these sites (Nordin et al. 2004, van Wijk et al. 2004) and alters their species composition (Graglia et al. 2001, Richardson et al. 2002). McKane et al. (2002) provide evidence that plants growing in cold climatic zones differ in timing, chemical form, and depth of nitrogen uptake. It remains unclear, though, why particular forms of nitrogen should be more strongly linked to species richness than others. Probably, high nitrate availability mainly increases grass biomass, which may lead to an out-shading of less competitive forb species (Willems et al. 1993).

At the $1000 \mathrm{~m}^{2}$ scale, the only significant factor explaining species richness was fertiliser application. It should be noted, though, that the statistical power to detect effects of the covariates at the $1000 \mathrm{~m}^{2}$ scale was much lower than at the $1 \mathrm{~m}^{2}$ scale (denominator DF at $1000 \mathrm{~m}^{2}=4$; at $1 \mathrm{~m}^{2}=130$ ). This may have influenced the results and explain why nitrate and the $V$. album $\times$ fertiliser interaction were only marginally significant at the $1000 \mathrm{~m}^{2}$ scale. Nevertheless, our results indicate that management interventions such as fertiliser application, which usually are carried out at the level of whole pastures, are more important determinants of large-scale species richness than parameters describing small-scale resource availability.

\section{The interacting effects of Veratrum album and land use on species richness}

Our study provides evidence that, apart from the well established direct effects of land use on species richness, there is also a link between land use and species richness via "mediator species" which promote or reduce species richness depending on land use. In our study, species richness was positively related to the abundance of the toxic $V$. album in fertilised pastures, where grazing pressure was strong. Our findings are in agreement with the results of Callaway et al. (2000) and Smit et al. (2006) and suggest indirect facilitation of other species by $V$. album. However, at abandoned sites species richness decreased with increasing abundance of $V$. album suggesting competition. At such sites $V$. album may out-compete other species due to decreased light availability under $V$. album (Kleijn and Müller-Schärer in press). Similarly, Callaway et al. (2005) reported that removing Veratrum lobelianum from sites where cattle grazing was permitted reduced species richness, whereas inside an exclosure the removal of Veratrum increased community richness. Veratrum album is generally seen as an undesirable species for agriculture, as it reduces fodder quality, but like other unpalatable species (Ellenberg 1989, Callaway et al. 2000), it may have positive effects on plant diversity if grazing is intense (Bertness and Callaway 1994).
At large scales, we found neither a relationship between species richness and the abundance of $V$. album nor between the land use types and the abundance of $V$. album, but both might be due to the low statistical power. One could assume that pastures with a high abundance of weeds are preferentially abandoned because of their low forage quality. We did not find support for this in our study, since the cover of $V$. album was similar at sites with different land use. Nevertheless, it is likely that, once a pasture has become invaded by $V$. album, cattle stocking will be reduced due to decreased forage quality. This in turn may promote the further spread of $V$. album, because trampling by cattle limits establishment of seedlings of $V$. album (Treier pers. comm.). Moreover, the presence of $V$. album increases the survival of tree saplings (Smit et al. 2006) in grazed pastures, and may therefore accelerate the process of a gradual abandonment and of reforestation of mountain grasslands.

\section{Conclusions}

Our study across five regions of the Alps indicates that different mechanisms influence species richness at different spatial scales. Unpalatable plants play an important role as mediator species by modifying the effect of land use on plant species diversity. At small scales nutrient availability and positive and negative interactions with unpalatable species determine species richness. Veratrum album reduces species richness in abandoned pastures, but preserves plant diversity when grazing is intense. At larger scales, plant species richness and vegetational composition are determined by management. This finding emphasizes the importance of studying effects of land use on species diversity especially at larger scales. Maintaining the traditional land use appears to be the most promising approach to conserve the high biodiversity of mountain grasslands.

Acknowledgements - This work was funded by the Swiss Priority Program (NFP 48) "Landscapes and Habitats of the Alps", a research project of the Swiss National Science Foundation (grant 4048-064424 to HMS and US). Field work was also supported by a travel grant from the Swiss Academy of Science to TS.

\section{References}

Austrheim, G. and Eriksson, O. 2001. Plant species diversity and grazing in the Scandinavian mountains - patterns and processes at different spatial scales. - Ecography 24: 683695.

Bertness, M. D. and Callaway, R. M. 1994. Positive interactions in communities. - Trends Ecol. Evol. 9: 191-193.

Binns, W. et al. 1972. Congenital deformation in lambs, calves and goats resulting from maternal ingestion of Veratrum californicum: hare clip, cleft palate, ataxia and hypoplasis of metacarpal and metatarsal bones. - Clin. Tox. 5: 245-261. 
Callaway, R. M. et al. 2000. Facilitation by unpalatable weeds may conserve plant diversity in overgrazed meadows in the Caucasus Mountains. - Oikos 89: 275-282.

Callaway, R. M. et al. 2005. Unpalatable plants protect neighbors from grazing and increase plant community diversity. - Ecology 86: 1856-1862.

Connell, J. H. 1978. Diversity in tropical rain forests and coral reefs. - Science 199: 1302-1310.

Crawley, M. J. and Harral, J. E. 2001. Scale dependence in plant biodiversity. - Science 291: 864-868.

Dufrene, M. and Legendre, P. 1997. Species assemblages and indicator species: the need for a flexible asymmetrical approach. - Ecol. Monogr. 67: 345-366.

Dullinger, S. et al. 2003. A resampling approach for evaluating effects of pasture abandonment on subalpine plant species diversity. - J. Veg. Sci. 14: 243-252.

Ellenberg, H. 1989. Opuntia dillenii as a problematic neophyte in the Yemen-Arab-Republic. - Flora 182: 3-12.

Ellenberg, H. et al. 1991. Zeigerwerte von Pflanzen in Mitteleuropa. - Goltze.

Erschbamer, B. et al. 2003. The impacts of vertebrate grazers on vegetation in Europe high mountains. - In: Nagy, L. et al. (eds), Alpine biodiversity in Europe. Springer, pp. 377-396.

Fischer, M. and Wipf, S. 2002. Effect of low-intensity grazing on the species-rich vegetation of traditionally mown subalpine meadow. - Biol. Conserv. 104: 1-11.

Graglia, E. et al. 2001. Effects of environmental perturbations on abundance of subarctic plants after three, seven and ten years of treatments. - Ecography 24: 5-12.

Hooper, D. U. et al. 2005. Effects of biodiversity on ecosystem functioning: a consensus of current knowledge. - Ecol. Monogr. 75: 3-35.

Huston, M. A. 1979. A general hypothesis of species diversity. - Am. Nat. 113: 81-101.

Huston, M. A. 1999. Local processes and regional patterns: appropriate scales for understanding variation in the diversity of plants and animals. - Oikos 86: 393-401.

Kleijn, D. and Steinger, T. 2002. Contrasting effects of grazing and hay cutting on the spatial and genetic populations structure of Veratrum album, an unpalatable, long-lived, clonal plant species. - J. Ecol. 90: 360-370.

Kleijn, D. and Müller-Schärer, H. in press. The relation between unpalatable species, nutrients and plant species richness in Swiss montane pastures. - Biodiv. Conserv.

Körner, C. 1999. Alpine plant life. - Springer.

Kruskal, J. B. 1964. Non-metric multidimensional scaling: a numerical method. - Psychometrika 29: 115-129.

Levine, J. M. et al. 2002. Neighbourhood scale effects of species diversity on biological invasions and their relationship to community patterns. - In: Loreau, M. et al. (eds), Biodiversity and ecosystem functioning - synthesis and perspectives. Oxford Univ. Press, pp. 114-124.

MacDonald, D. et al. 2000. Agriculture abandonment in mountain areas of Europe: environmental consequences and policy response. - J. Environ. Manage. 59: 47-69.

McCune, B. and Mefford, M. J. 1999. PC-ORD. Multivariate analysis of ecological data, ver. 4.0 - MJM Software Design, Gleneden Beach, OR.

McKane, R. B. et al. 2002. Resource-based niches provide a basis for plant species diversity and dominance in arctic tundra. - Nature 415: 68-71.

Milchunas, D. G. et al. 1988. A generalized model of the effects of grazing by large herbivores on grassland community structure. - Am. Nat. 132: 87-106.
Minchin, P. R. 1987. An evaluation of relative robustness of techniques for ecological ordinations. - Vegetatio 7: $145-156$

Müller, P. et al. 2003. Einfluss von Boden und Bewirtschaftung auf die Artenvielfalt der Vegetation auf Alpweiden im Glarnerland. - Bot. Helv. 113: 15-36.

Nagy, L. et al. (eds) 2003. Alpine biodiversity in Europe. - Springer.

Newman, E. I. 1973. Competition and diversity in herbaceous vegetation. - Nature 244: 310-311.

Nordin, A. et al. 2004. Nitrogen uptake by artic soil microbes and plants in relation to soil nitrogen supply. - Ecology 85 : 955-962.

Oksanen, J. 1990. Predation, herbivory, and plant strategies along gradients of primary production. - In: Grace, J. and Tilman, D. (eds), Perspectives on plant competition. Academic Press, pp. 445-474.

Oksanen, L. and Moen, J. 1994. Species-specific plant responses to exclusion of grazers in three Fennoscandian tundra habitats. - Ecoscience 1: 31-39.

Olff, H. and Ritchie, M. E. 1998. Effects of herbivores on grassland plant diversity. - Trends Ecol. Evol. 13: 261-265.

Olsen, S. R. et al. 1954. Estimation of available phosphorus in soils by extraction with sodium bicarbonate. - U.S. Dept of Agricult. Circ. 939.

Richardson, S. J. et al. 2002. How do nutrients and warming impact on plant communities and their insect herbivores? A 9-year study from a sub-Arctic heath. - J. Ecol. 90: 544556.

Shepard, R. N. 1962. The analysis of proximities: multidimensional scaling with an unknown distance function. Psychometrika 27: 125-139.

Smit, C. et al. 2006. Unpalatable plants facilitate tree sapling survival in wooded pastures. - J. Appl. Ecol. 43: 305-312.

Stampfli, A. 1992. Year-to-year changes in unfertilized meadows of great species richness detected by point quadrate analysis. - Vegetatio 103: 125-132.

Stampfli, A. and Zeiter, M. 1999. Plant species decline due to abandonment of meadows cannot easily be reversed by mowing. A case study from the southern Alps. - J. Veg. Sci. 10: $151-164$.

Stohlgren, T. J. et al. 1999. Exotic plant species invade hot spots of native plant diversity. - Ecol. Monogr. 69: 25-46.

Tasser, E. and Tappeiner, U. 2002. Impact of land use changes on mountain vegetation. - Appl. Veg. Sci. 5: 173-184.

Theodose, T. A. and Bowman, W. D. 1997. Nutrient availability, plant abundance, and species diversity in two alpine tundra communities. - Ecology 78: 1861-1872.

Tilman, D. 1994. Competition and biodiversity in spatially structured habitats. - Ecology 75: 2-16.

Tilman, D. 1997. Community invasibility, recruitment limitation, and grassland biodiversity. - Ecology 78: 81-92.

van Wijk, M. T. et al. 2004. Long-term ecosystem level experiments at Toolik Lake, Alaska, and at Abisko, northern Sweden: generalizations and differences in ecosystem and plant type responses to global change. - Global Change Biol. 10: 105-123.

WallisDeVries, M. F. et al. (eds) 1998. Grazing and conservation management. - Kluwer.

Willems, J. H. et al. 1993. Changes in chalk-grassland structure and species richness resulting from selective nutrient additions. - J. Veg. Sci. 4: 203-212.

Zobel, M. et al. 2000. Is small-scale species richness limited by seed availability or microsite availability? - Ecology 81 : $3274-3282$.

Download the appendix as file E4631 from

$<$ www. oikos.ekol.lu.se/appendix $>$.

Subject Editor: Francisco Pugnaire. 
Ecography

E4631

Spiegelberger, T., Matthies, D., Müller-Schärer, H. and Schaffner, U. 2006. Scale-dependent effects of land use on plant species richness of mountain grassland in the European Alps. - Ecography 29: 541-548.

Appendix 1. Description of study sites in France (F) and Switzerland (CH). Type of land use: F, fertilised; T, traditional; A, abandoned pasture.

\begin{tabular}{|c|c|c|c|c|c|c|c|}
\hline Country & Region & $\begin{array}{l}\text { Land } \\
\text { use }\end{array}$ & $\begin{array}{l}\text { Eleva- } \\
\text { tion }\end{array}$ & $\begin{array}{l}\text { Incli- } \\
\text { nation }\end{array}$ & $\begin{array}{l}\text { Expo- } \\
\text { sition }\end{array}$ & $\begin{array}{l}\text { Cattle } \\
\text { density ha }{ }^{-1}\end{array}$ & $\begin{array}{l}\% \text { cover } \\
\text { V. album }\end{array}$ \\
\hline $\mathrm{F}$ & Bauges & $\mathrm{F}$ & $1628 \mathrm{~m}$ & $18 \%$ & W & 1.2 & 15.9 \\
\hline F & Bauges & $\mathrm{T}$ & $1607 \mathrm{~m}$ & $27 \%$ & W & 0.8 & 3.5 \\
\hline $\mathrm{F}$ & Bauges & A & $1755 \mathrm{~m}$ & $36 \%$ & NW & - & 3.2 \\
\hline $\mathrm{F}$ & Beaufortin & $\mathrm{F}$ & $1914 \mathrm{~m}$ & $25 \%$ & NWN & 1.3 & 3.3 \\
\hline $\mathrm{F}$ & Beaufortin & $\mathrm{T}$ & $1891 \mathrm{~m}$ & $23 \%$ & NNW & 0.4 & 3.5 \\
\hline $\mathrm{F}$ & Beaufortin & A & $1838 \mathrm{~m}$ & $29 \%$ & WNW & - & 3.6 \\
\hline F & Chablais & $\mathrm{F}$ & $1550 \mathrm{~m}$ & $36 \%$ & NNW & 1.4 & 3.3 \\
\hline F & Chablais & $\mathrm{T}$ & $1470 \mathrm{~m}$ & $36 \%$ & NNW & 1.0 & 4.0 \\
\hline $\mathrm{F}$ & Chablais & A & $1470 \mathrm{~m}$ & $36 \%$ & NNW & - & 2.0 \\
\hline $\mathrm{CH}$ & Chablais & $\mathrm{F}$ & $1539 \mathrm{~m}$ & $47 \%$ & W & 1.8 & 4.3 \\
\hline $\mathrm{CH}$ & Chablais & $\mathrm{T}$ & $1409 \mathrm{~m}$ & $20 \%$ & W & 0.9 & 24.6 \\
\hline $\mathrm{CH}$ & Chablais & A & $1517 \mathrm{~m}$ & $31 \%$ & WSW & - & 24.3 \\
\hline $\mathrm{CH}$ & Lac de Dix & $\mathrm{F}$ & $1255 \mathrm{~m}$ & $36 \%$ & NW & 1.4 & 4.3 \\
\hline $\mathrm{CH}$ & Lac de Dix & $\mathrm{T}$ & $1646 \mathrm{~m}$ & $32 \%$ & WSW & 0.8 & 5.5 \\
\hline $\mathrm{CH}$ & Lac de Dix & A & $1507 \mathrm{~m}$ & $79 \%$ & SW & - & 4.5 \\
\hline
\end{tabular}


Appendix 2. Indicator species analysis (Dufrene and Legendre 1997) for plant species of mountain grasslands in the Alps. All p-values $<0.01$. Species are arranged according to the land use type they indicate $(F=$ fertilised pastures; $T=$ traditional pastures; $A=$ abandoned pastures).

\begin{tabular}{|c|c|c|c|c|c|c|c|}
\hline \multirow[t]{2}{*}{ Species } & \multirow{2}{*}{$\begin{array}{l}\text { Indicator } \\
\text { species } \\
\text { for }\end{array}$} & \multicolumn{3}{|c|}{$\begin{array}{l}\text { Cumulative } \\
\text { presence }\end{array}$} & \multicolumn{3}{|c|}{$\begin{array}{l}\text { Mean } \\
\text { cover }\end{array}$} \\
\hline & & $\mathrm{F}$ & $\mathrm{T}$ & A & $\mathrm{F}$ & $\mathrm{T}$ & A \\
\hline Festuca rubra & $\mathrm{F}$ & 46 & 45 & 35 & 9.4 & 8.6 & 3.1 \\
\hline Cynosurus cristatus & $\mathrm{F}$ & 35 & 21 & 19 & 6.0 & 2.6 & 2.2 \\
\hline Anthoxanthum odoratum & $\mathrm{F}$ & 29 & 21 & 12 & 3.6 & 1.7 & 1.2 \\
\hline Taraxacum officinale & $\mathrm{F}$ & 25 & 10 & 10 & 1.4 & 0.5 & 0.6 \\
\hline Luzula alpinopilosa & $\mathrm{F}$ & 24 & 22 & 1 & 2.0 & 0.9 & 0.1 \\
\hline Leontodon autumnalis & $\mathrm{F}$ & 22 & 8 & 1 & 1.1 & 0.3 & 0.1 \\
\hline Carum carvi & $\mathrm{F}$ & 17 & 7 & 3 & 2.7 & 0.4 & 0.0 \\
\hline Phleum phleoides & $\mathrm{F}$ & 10 & 0 & 0 & 3.1 & 0.0 & 0.0 \\
\hline Knautia dipsacifolia & $\mathrm{F}$ & 7 & 0 & 1 & 0.1 & 0.0 & 0.0 \\
\hline Trifolium pratensis & $\mathrm{T}$ & 36 & 38 & 15 & 1.7 & 2.6 & 0.8 \\
\hline Leucanthemum vulgare & $\mathrm{T}$ & 5 & 21 & 12 & 0.1 & 0.5 & 0.3 \\
\hline Lotus corniculatus & $\mathrm{T}$ & 8 & 18 & 4 & 0.3 & 0.9 & 0.1 \\
\hline Geum montanum & $\mathrm{T}$ & 5 & 17 & 3 & 0.2 & 0.5 & 0.1 \\
\hline Crepis aurea & $\mathrm{T}$ & 6 & 16 & 0 & 0.1 & 0.7 & 0.0 \\
\hline Homogyne alpina & $\mathrm{T}$ & 1 & 15 & 4 & 0.0 & 0.6 & 0.2 \\
\hline Phyteuma orbiculare & $\mathrm{T}$ & 4 & 14 & 2 & 0.1 & 0.4 & 0.0 \\
\hline Cirsium acaule & $\mathrm{T}$ & 0 & 14 & 0 & 0.0 & 0.7 & 0.0 \\
\hline Hieracium lactucella & $\mathrm{T}$ & 6 & 12 & 0 & 0.2 & 0.6 & 0.0 \\
\hline Polygala vulgaris & $\mathrm{T}$ & 0 & 10 & 1 & 0.0 & 0.2 & 0.0 \\
\hline Phyteuma betonicifolium & $\mathrm{T}$ & 0 & 10 & 0 & 0.0 & 0.2 & 0.0 \\
\hline Arnica montana & $\mathrm{T}$ & 0 & 10 & 0 & 0.0 & 1.5 & 0.0 \\
\hline Alchemilla flabellata & $\mathrm{T}$ & 0 & 10 & 0 & 0.0 & 0.5 & 0.0 \\
\hline Poa pratensis & $\mathrm{T}$ & 0 & 9 & 2 & 0.0 & 2.2 & 0.4 \\
\hline Myosotis sylvatica & $\mathrm{T}$ & 1 & 9 & 0 & 0.0 & 0.2 & 0.0 \\
\hline Galium mullogo & $\mathrm{T}$ & 0 & 9 & 1 & 0.0 & 0.1 & 0.0 \\
\hline Holcus mollis & $\mathrm{T}$ & 0 & 8 & 1 & 0.0 & 1.2 & 0.0 \\
\hline Centaurea pseudophrygia & $\mathrm{T}$ & 3 & 8 & 0 & 0.2 & 0.8 & 0.0 \\
\hline Carex sempervirens & $\mathrm{T}$ & 0 & 8 & 0 & 0.0 & 0.5 & 0.0 \\
\hline Orchis mascula & $\mathrm{T}$ & 0 & 6 & 0 & 0.0 & 0.1 & 0.0 \\
\hline Gagea fistulosa & $\mathrm{T}$ & 0 & 6 & 0 & 0.0 & 0.1 & 0.0 \\
\hline Deschampsia caespitosa & A & 7 & 25 & 28 & 0.7 & 4.2 & 8.4 \\
\hline Chaerophyllum hirsutum & A & 33 & 43 & 48 & 1.9 & 4.6 & 6.5 \\
\hline Geranium sylvaticum & A & 22 & 34 & 39 & 1.4 & 2.5 & 5.1 \\
\hline Heracleum sphondylium & A & 2 & 0 & 7 & 0.1 & 0.0 & 2.6 \\
\hline Phleum pratensis & A & 0 & 10 & 16 & 0.0 & 0.9 & 1.6 \\
\hline Rubus sp. & A & 0 & 0 & 7 & 0.0 & 0.0 & 1.3 \\
\hline Bromus erectus & A & 3 & 0 & 8 & 0.1 & 0.0 & 1.2 \\
\hline Equisetum sylvaticum & A & 0 & 0 & 8 & 0.0 & 0.0 & 0.8 \\
\hline Hypericum maculatum & A & 9 & 14 & 21 & 0.1 & 0.2 & 0.7 \\
\hline Carex montana & A & 0 & 0 & 6 & 0.0 & 0.0 & 0.6 \\
\hline Rosa canina & A & 0 & 0 & 8 & 0.0 & 0.0 & 0.4 \\
\hline Myosotis decumbens & A & 0 & 0 & 8 & 0.0 & 0.0 & 0.4 \\
\hline Centaurea jacea & A & 6 & 2 & 15 & 0.1 & 0.0 & 0.4 \\
\hline Cardamine pratensis & A & 0 & 0 & 8 & 0.0 & 0.0 & 0.1 \\
\hline
\end{tabular}

